\title{
ANALISIS KADAR TRIGLISERIDA PADA PELARI BERDASARKAN JENIS LARI YANG DILAKUKAN
}

\author{
Ni Luh Putu Pebrita Anjar Santi ${ }^{1}$, Ida Bagus Rai Wiadnya ${ }^{2}$, Lale Budi Kusuma Dewi ${ }^{3}$ \\ ${ }^{1,2,3}$ Jurusan Analis Kesehatan, Poltekkes Kemenkes Mataram, Indonesia.
}

\begin{tabular}{l}
\hline \hline Article Info \\
\hline Article history: \\
Received Jan $17^{\text {th }}, 2019$ \\
Revised Jan $29^{\text {th }}, 2019$ \\
Accepted Feb $2^{\text {nd }}, 2019$ \\
\hline
\end{tabular}

\section{Keyword:}

Trigliserida

Lari

\begin{abstract}
Triglycerides are one of the fats in the body. Increased triglyceride levels occur due to obesity, alcohol consumption, and lack of activity, causing a buildup of triglycerides in the blood. Decreasing triglyceride levels can be done in various ways, one of which is to regulate lifestyle patterns such as diet regulation and physical activity. Objective: To determine the effect of the types of running on triglyceride levels on runners. Research Methods: This study is a Pre-Experiment. The number of samples used was 27 people. The results of the study in the form of runner triglyceride levels were analyzed using the Wilcoxon Signed Ranks Test to see differences in the results of triglyceride levels before and after running. Research Results: The results obtained from this study were before running $(119,56)>$ after $100 \mathrm{~m}$ run $(75,11)$, before running $(88,11)>$ after a $1500 \mathrm{~m}$ run $(67,22)$, before running $(71,44)>$ after running $5000 \mathrm{~m}$ $(56,33)$. The results of the Wilcoxon Signed Ranks Test show that the probability in the $100 \mathrm{~m}$ and $1500 \mathrm{~m}$ run group is (Sig) 0.008 and in the $5000 \mathrm{~m}$ run group is (Sig) 0.007 which means that the $\mathrm{P}<\alpha 0.05$ value. Conclusion: The farther the distance a runner traveled, the greater the triglyceride level obtained by the runner.
\end{abstract}

Copyright (C) JurnalAnalisMedika Bio Sains All rights reserved.

\begin{abstract}
ABSTRAK
Latar belakang : Trigliserida merupakan salah satu lemak didalam tubuh. Peningkatan kadar trigliserida terjadi karena kegemukan, konsumsi alkohol, serta kurangnya aktivitas sehingga menyebabkan penumpukan trigliserida dalam darah. Penurunan kadar trigliserida dapat dilakukan dengan berbagai cara, salah satunya adalah dengan mengatur gaya pola hidup seperti pengaturan diet dan aktivitas fisik. Tujuan Penelitian : Untuk mengetahui pengaruh jenis - jenis lari terhadap kadar trigliserida pada pelari. Metode Penelitian : Penelitian ini adalah Pra-Experiment. Jumlah sampel yang digunakan sebanyak 27 orang. Hasil penelitian berupa kadar trigliserida pelari dianalisis menggunakan uji Wilcoxon Signed Ranks Test untuk melihat perbedaan hasil kadar trigliserida sebelum dan setelah melakukan lari. Hasil Penelitian : Hasil yang didapatkan dari penelitian ini adalah sebelum lari $(119,56)$ $>$ setelah lari 100m $(75,11)$, sebelum lari $(88,11)>$ setelah lari 1500m $(67,22)$, sebelum lari $(71,44)>$ setelah lari 5000m (56,33). Hasil uji Wilcoxon Signed Ranks Test menunjukkan probabilitas pada kelompok lari 100m dan 1500m adalah (Sig) 0,008 dan pada kelompok lari 5000m adalah (Sig) 0,007 yaitu hasil tersebut berarti nilai $\mathrm{P}<\alpha$ 0,05. Kesimpulan : Semakin jauh jarak lari yang ditempuh seorang pelari maka semakin besar pula penurunan kadar trigliserida yang didapat oleh pelari tersebut.
\end{abstract}

Kata Kunci : Jenis lari, Trigliserida.

Pendahuluan

Copyright (C) JurnalAnalisMedika Bio Sains 

Olahraga adalah salah satu bentuk kegiatan yang dilakukan secara terencana dan terstruktur, yang melibatkan gerakan tubuh berulang-ulang dan bermanfaat untuk meningkatkan kebugaran jasmani. Salah satu jenis latihan olahraga yaitu latihan aerobik, adapun contoh-contoh latihan aerobik ialah berjalan, jogging, berenang, bersepeda, loncattali, senam aerobik, lari dan lain sebagainya. ${ }^{1}$

Pada olahraga aerobik terjadi metabolisme energi yang berjalan melalui pembakaran simpanan lemak, karbohidrat, dan sebagian kecil (kurang dari lima persen) dari pemecahan simpanan protein yang terdapat dalam tubuh. Proses metabolisme ini berjalan dengan adanya oksigen yang diperoleh melalui proses pernapasan. ${ }^{2}$

Lemak yang terdapat dalam zat makanan umumnya terdiri dari tiga gugus asam lemak dengan gliserol yang dikenal sebagai trigliserida. Trigliserida merupakan salah satu dari jenis-jenis lemak yang terdapat di dalam darah dan berbagai organ tubuh lainnya. ${ }^{3}$ Trigliserida dibentuk dari gliserol dan lemak yang berasal dari makanan dengan menggunakan rangsangan insulin atau kelebihan dari kalori akibat makan secara berlebih. Kelebihan kalori akan diubah menjadi trigliserida dan disimpan sebagai lemak dibawah kulit. ${ }^{4}$

\section{Metode Penelitian}

Penelitian ini merupakan penelitian PraEksperiment. Rancangan penelitian yang digunakan adalah One group pretest-postest. Sampel yang digunakan adalah darah vena dari orang yang melakukan kegiatan olahraga
Peningkatan kadar lemak khususnya kadar trigliserida akhir-akhir ini mendapat perhatian luas di kalangan masyarakat, terutama pada seseorang yang asupan lemaknya cukup tinggi dan kurangnya melakukan aktivitas olahraga.

Peningkatan kadar trigliserida dapat disebabkan oleh kelebihan karbohidrat, lemak atau lainnya. Akibatnya, terjadi penumpukan pada pembuluh darah sehingga menyebabkan terganggunya metabolisme tubuh. Peningkatan kadar trigliserida akan menambah risiko terjadinya stroke, diabetes, gangguan tekanan darah, dan penyakit jantung. ${ }^{5}$

Penurunan kadar trigliserida dalam darah dapat dilakukan dengan berbagai cara, salah satunya dengan mengonsumsi obat-obatan dan juga dengan mengatur pola gaya hidup. Perubahan gaya hidup ini juga mampu dilakukan dengan pengaturan diet dan aktivitas fisik. $^{6}$

Kadar trigliserida didalam tubuh juga dapat membahayakan kesehatan apabila tidak di jaga kenormalan kadarnya. Adapun langkah yang dapat diambil untuk mengatur kenormalan kadar trigliserida yaitu dengan mengubah pola gaya hidup dengan rajin berolahraga. Tujuan dari penelitian ini adalah untuk mengetahui jenis - jenis lari terhadap kadar trigliserida pada pelari.

lari di Lapangan Gebang, Kota Mataram. Besar sampel dalam penelitian ini ditetapkan dengan menggunakan rumus Federer sehingga besar sampel yang digunakan yaitu sebanyak 27 sampel. Cara pengambilan sampel dalam 
penelitian ini adalah dengan non random purposive sampling, yaitu pengambilan sampel yang didasarkan pada suatu kriteria tertentu yang dibuat oleh peneliti sendiri dan berdasarkan ciri atau sifat-sifat populasi yang sudah diketahui. Pemeriksaan trigliserida

Hasil Penelitian dan Pembahasan

Hasil pemeriksaan kadar trigliserida yang diperiksa menggunakan alat Photometer 5010 dilakukan sebanyak 2 kali yaitu sebelum melakukan lari dan setelah melakukan lari. Data hasil penelitian disajikan dalam bentuk table kemudian di analisis secara statistic menggunakan uji One Way Annova

pada relawan dapat dilihat pada table di bawah ini:

Tabel 1. Data Hasil Pemeriksaan Kadar Trigliserida Pada Lari dengan Jarak 100m

\begin{tabular}{c|c|c|c}
\hline \multirow{2}{*}{ No sampel } & \multicolumn{3}{|c}{ Kadar Trigliserida $(\mathrm{mg} / \mathrm{dL})$} \\
\cline { 2 - 4 } & Sebelum lari & Setelah lari & Selisih \\
\hline 1 & 169 & 104 & 65 \\
2 & 79 & 47 & 32 \\
3 & 109 & 79 & 30 \\
4 & 87 & 55 & 32 \\
5 & 92 & 75 & 17 \\
6 & 149 & 85 & 64 \\
7 & 183 & 102 & 81 \\
8 & 140 & 102 & 38 \\
9 & 68 & 27 & 41 \\
\hline Total & 1076 & 676 & 400 \\
\hline Rerata & 119,56 & 75,11 & 44,44
\end{tabular}

Tabel 1 menunjukkan bahwa rerata hasil pemeriksaan kadar trigliserida sebelum melakukan lari adalah 119,56 $\mathrm{mg} / \mathrm{dL}$ dan rerata setelah lari 100m adalah 75,11 dengan hasil selisih adalah 44,44 $\mathrm{mg} / \mathrm{dL}$.

Tabel 2. Data Hasil Pemeriksaan Kadar Trigliserida Pada Lari dengan Jarak 1500m

\begin{tabular}{c|c|c|c}
\hline \multirow{2}{*}{$\begin{array}{c}\text { No } \\
\text { sampel }\end{array}$} & \multicolumn{3}{|c}{ Kadar Trigliserida (mg/dL) } \\
\cline { 2 - 4 } & Sebelum lari & Setelah lari & Selisih \\
\hline 1 & 105 & 85 & 20 \\
3 & 68 & 57 & 11 \\
4 & 121 & 105 & 16 \\
5 & 119 & 111 & 8 \\
6 & 72 & 33 & 39 \\
7 & 84 & 73 & 11 \\
8 & 124 & 55 & 69 \\
9 & 34 & 28 & 6 \\
\hline Total & 66 & 58 & 8 \\
\hline Rerata & 893 & 605 & 188 \\
\hline
\end{tabular}


Tabel 2 menunjukkan bahwa rerata hasil pemeriksaan kadar trigliserida sebelum melakukan lari adalah 88,11 $\mathrm{mg} / \mathrm{dL}$ dan rerata setelah lari sejauh $1500 \mathrm{~m}$ adalah 67,22 dengan hasil selisih adalah $20,89 \mathrm{mg} / \mathrm{dL}$.

Tabel 3. Data Hasil Pemeriksaan Kadar Trigliserida Pada Lari dengan Jarak 5000m

\begin{tabular}{c|c|c|c}
\hline \multirow{2}{*}{$\begin{array}{c}\text { No } \\
\text { sampel }\end{array}$} & \multicolumn{3}{|c}{ Trigliserida } \\
\cline { 2 - 4 } & Sebelum lari & Setelah lari & Selisih \\
\hline 1 & 49 & 48 & 1 \\
2 & 61 & 46 & 15 \\
3 & 68 & 64 & 4 \\
4 & 84 & 70 & 14 \\
5 & 68 & 47 & 21 \\
6 & 103 & 66 & 37 \\
7 & 88 & 52 & 36 \\
8 & 57 & 53 & 4 \\
9 & 65 & 61 & 4 \\
\hline Total & 643 & 507 & 136 \\
\hline Rerata & 71,44 & 56,33 & 15,11 \\
\hline
\end{tabular}

Tabel 3 menunjukkan bahwa rerata hasil pemeriksaan kadar trigliserida sebelum melakukan lari adalah 71,44 $\mathrm{mg} / \mathrm{dL}$ dan rerata setelah lari sejauh $5000 \mathrm{~m}$ adalah $56,33 \mathrm{mg} / \mathrm{dL}$ dengan hasil selisih adalah $15,11 \mathrm{mg} / \mathrm{dL}$. a. Analisis Data

1. Uji Normalitas

Hasil uji normalitas, dapat dilihat pada table 4.4:

Tabel 4. Hasil Analisis Uji Normalitas

\begin{tabular}{|c|c|c|}
\hline No & Jarak & Hasil Uji Normalitas \\
\hline 1 & $\begin{array}{cc}\text { Sebelum lari } & 100 \mathrm{~m} \\
& 1500 \mathrm{~m} \\
& 5000 \mathrm{~m}\end{array}$ & $\begin{array}{l}0,433 \\
0,367 \\
0,600\end{array}$ \\
\hline 2 & $\begin{aligned} \text { Setelah lari } 100 \mathrm{~m} \\
1500 \mathrm{~m} \\
5000 \mathrm{~m}\end{aligned}$ & $\begin{array}{l}0,433 \\
0,367 \\
0,600\end{array}$ \\
\hline
\end{tabular}

Dari tabel 4 menunjukkan hasil uji normalitas untuk data hasil penelitian perbedaan kadar trigliserida sebelum dan setelah lari sejauh 100m, 1500m dan $5000 \mathrm{~m}$ berdistribusi normal, dibuktikan dengan nilai probabilitas $>\alpha=0,05$.
2. Uji Homogenitas

Uji homogenitas atau uji Levene's Test ini dilakukan untuk mengetahui data yang dianalisis homogen atau tidak. Adapun hasil dari uji homogenitas yang telah dilakukan dapat dilihat pada tabel 5 . 

Tabel 5. Hasil Analisis Homogenitas

\begin{tabular}{c|c|c}
\hline No & Jarak & Hasil Uji Homogenitas \\
\hline 1 & Sebelum lari & 0,007 \\
2 & Setelah lari & 0,029 \\
\hline
\end{tabular}

Berdasarkan hasil uji homogenitas di atas, didapatkan hasil 0,007 sebelum lari dan 0,029 setelah lari, maka hasil dikatakan tidak homogen karena nilai tersebut $<0,05$.

3. Uji Beda Hasil Pemeriksaan Kadar Trigliserida

Untuk mengetahui perbedaan hasil jumlah pemeriksaan kadar trigliserida pada dua perlakuan sampel tersebut dilakukan dengan analisa Uji Wilcoxon Signed Ranks Test, dengan tingkat kepercayaan $95 \% \mathrm{P}(\alpha=0,05)$. Uji statistik ini dilakukan dengan bantuan komputer program SPSS. Adapun hasil uji Beda Kadar Trigliserida dapat dilihat pada table di bawah ini:

Tabel 6. Hasil Analisa Uji Beda Kadar Trigliserida

\begin{tabular}{c|c|c|c}
\hline \multirow{2}{*}{ No } & \multicolumn{3}{|c}{ Test Statistic } \\
\cline { 2 - 4 } & $100 \mathrm{~m}$ & $1500 \mathrm{~m}$ & $5000 \mathrm{~m}$ \\
\hline 1 & 0,008 & 0,008 & 0,007 \\
\hline
\end{tabular}

Data hasil uji statistik pada tabel 6 terlihat bahwa nilai signifikan hasil pemeriksaan kadar trigliserida antara sebelum melakukan lari dan setelah melakukan lari sejauh 100m, $1500 \mathrm{~m}$ dan $5000 \mathrm{~m}$ yaitu pada lari sejauh $100 \mathrm{~m}$ dan $1500 \mathrm{~m}$ memiliki nilai probabilitas (Sig) 0,008 sedangkan pada lari sejauh 5000m memiliki nilai probabilitas (Sig) 0,007 oleh karena itu nilai probabilitas $<\alpha \quad 0,05$ maka Ho ditolak dan $\mathrm{Ha}$ di terima berarti ada perbedaan yang bermakna terhadap hasil pemeriksaan kadar trigliserida sebelum dan setelah lari sejauh 100m, 1500m dan $5000 m$ pada pelari di Lapangan Gebang, Mataram.

\section{b. Pembahasan}

Kadar trigliserida dalam darah dapat dipengaruhi oleh berbagai sebab, diantaranya: Faktor Genetik, Jenis Kelamin, usia, olahraga atau aktivitas fisik. Selain itu juga kadar trigliserida dapat dipengaruhi oleh asupan makanan, rokok, dan mengonsumsi alkohol. 
Berdasarkan jarak tempuh yang digunakan dalam penelitian ini maka terdapat dua kelompok jenis olahraga yaitu olahraga aerobik pada lari dengan jarak tempuh $1500 \mathrm{~m}$ dan 5000m, sedangkan olahraga anaerobik pada lari dengan jarak tempuh 100m (Sprint).

Sebelum lari, pelari melakukan pemanasan atau peregangan selama lebih kurang 5 menit kemudian setelah itu pelari melakukan lari dengan masing-masing waktu tempuh yang digunakan adalah 100m selama lebih kurang 30 detik, 1500m selama 7 menit dan 5000m selama 25 menit.

Pelari yang digunakan dalam penelitian ini memiliki usia rata-rata 20 sampai dengan 30 tahun, dengan tinggi badan rata-rata 160 sampai dengan $175 \mathrm{~cm}$ dan berat badan rata-rata 60 sampai dengan $70 \mathrm{~kg}$.

Berdasarkan hasil penelitian yang telah dilakukan di lapangan Gebang, Mataram diperoleh rerata hasil pemeriksaan kadar trigliserida adalah sebelum lari $(119,56)>$ setelah lari $100 \mathrm{~m}$ $(75,11)$, sebelum lari $(88,11)>$ setelah lari 1500m $(67,22)$, sebelum lari $(71,44)>$ setelah lari 5000m (56,33). Hal ini menunjukkan bahwa semakin jauh jarak lari yang ditempuh oleh pelari tersebut maka terjadinya penurunan kadar trigliserida semakin besar. Tetapi, berdasarkan jarak tempuh yang digunakan pada penelitian ini penurunan kadar trigliserida juga dipengaruhi oleh intensitas olahraga yang dilakukan pelari seperti lari sprint, meskipun jarak pendek tetapi lari sprint memerlukan lebih banyak energi dalam melakukannya, akan tetapi hasil yang didapat lebih besar terhadap penurunan kadar trigliserida karena proses pembakaran lemak yang lebih banyak.

Adapun manfaat yang dimiliki dari olahraga tersebut yaitu kolesterol total yang lebih rendah, trigliserida yang lebih rendah, HDL yang lebih tinggi, tekanan darah yang lebih rendah, pengendalian gula darah yang lebih baik, jantung yang lebih sehat memompakan darah secara lebih efisien. Olahraga aerobik cukup membantu untuk menstimulasi dan tidak membuat stress namun harus menimbulkan usaha, tetapi usaha yang tidak terlalu melelahkan sebaiknya dilakukan 20-30 menit atau lebih. $^{7}$

Olahraga adalah salah satu aktivitas fisik yang dapat membantu menjaga atau menurunkan berat badan jika kita sedang dalam kondisi kegemukan atau berat badan yang berlebih dan untuk menjaga kebugaran tubuh serta dapat mengendalikan stress. Diharapkan dengan melakukan berbagai aktivitas fisik dapat mencapai berat badan ideal dan akan menjaga kenormalan kadar kolesterol dan kadar trigliserida di dalam darah serta dapat membantu menjaga kesehatan tubuh. $^{8}$ 


\section{Kesimpulan}

Semakin jauh jarak lari yang dilakukan maka semakin besar pula penurunan kadar trigliserida yang didapatkan pelari tersebut. Akan tetapi, pada penelitian ini juga dilakukan lari cepat jarak pendek yang juga menunjukkan hasil penurunan kadar trigliserida setelah lari yang lebih besar karena energi yang digunakan lebih tinggi sehingga pembakaran lemak trigliserida lebih banyak.

\section{Daftar Pustaka}

1. Ali, M.A., 2013. Pengaruh Latihan Aerobik terhadap Peningkatan Kadar High Density Lipoprotein pada atlet Aerobic Gymnastics.,

2. Palar, Chrisly M., 2015. Manfaat Latihan Olahraga Aerobik Terhadap Kebugaran Fisik Manusia. Jurnal e-Biomedik, 3 (April).

3. Soeharto, Imam., 2001. Kolesterol dan Lemak Jahat, Kolesterol dan Lemak Baik, dan Proses Terjadinya Serangan Jantung dan Stroke. Jakarta: PT. Gramedia PustakaUtama.

4. Dalimartha S., 2011. 36 Resep Tumbuhan Obat untuk Menurunkan Kolesterol (edisi revisi). Jakarta: Penebar Swadaya.

5. Agnes Sri Harti. 2014. Biokimia Kesehatan. Yogyakarta: Nuha Medika.

6. Reinezer Z, Catapano AL, Backer GD, Graham I, Taskinen MR, Wiklund $\mathrm{O}$ et al. ESC/EAS Guidelines for the management of dysplidemias. European Heart Journal, 2011; 32.
7. Grandjean, P.W, F.C. Stephen, and J.J. Rohack. 2000. Influence of cholesterol Status on Blood Lipid and Lipoprotein Enzyme Responses to Aerobic Exercise.J Appl Physiol.

8. Saragih, Dr. Bernatal. (2017). Kolesterol dan Usaha-usaha Penurunannya. Penerbit: Bimotry 
